\title{
Transmedia a sztuka Roberta Wilsona
} czątkowało serię przemian $\mathrm{w}$ kulturze. Zjawisko przenikania się poszczególnych narracji przynależnych pojedynczym mediom - kontaminowanie, integracja, interakcja komunikatów wpłynęły na kształtowanie się nowego „transmedialnego" [2] języka. Termin transmedia zyskał bardzo duże znaczenie w ostatnim czasie we współczesnej humanistyce (zajmującej się zarówno kulturą, jak i procesami percepcjina przykład kognitywistyka), ale także w naukach ścisłych zarówno tych, których źródłem jest matematyka (jak informatyka i cybernetyka), ale i medycyna (tu neurologia), czy też w obecnych naukach biologiczno-psychologicznych. Formą narracji przynależną współczesności jest „opowiadanie transmedialne” (transmedia storytelling), w skrócie: interaktywne z odbiorcą przekazywanie i równoczesne rozwijanie (na zasadzie uzupełniania danych[3]) tego samego pakietu informacji poprzez różne kanały dystrybucyjne (telekomunikacja, sieć internetowa,

[1] W tekście wielokrotnie posługuję się terminem „media”. Jego zakres znaczeniowy staram się zawsze zasugerować osadzając ten termin w konkretnym kontekście, dla jasności ważne jest jednak zakreślenie pewnego obszaru, do którego odnoszę słowo medium. Bliskie są mi współczesne definicje tego słowa wypracowane przez teoretyków komunikacji nowych mediów (takich jak Lev Manovich, Henry Jenkins), naukowców zajmujących się współczesną kulurą wizualną (między innymi Martin Lister czy Jon Dovey) oraz praktyków badających możliwości deformacji i przetransponowywania mediów w takich placówkach jak laboratoria MIT oraz Reality Mixed Lab na Uniwersytecie Nottingham. Wszystkie te definicje będą uciekać od wąskich omówień tego terminu, ze względu na specyfikę samych mediów we współczesności, a właściwie w całym XX wieku. Każda obecnie tworzona definicja, która chciałaby w sobie zawrzeć nie tylko pozorne cechy opisowe nośnika informacji oraz jej ewentualnej struktury, skazana jest na bardzo krótki żywot ze względu na silne zdynamizowanie tego obszaru. Granice pomiędzy poszczególnymi mediami są bardzo płynne a ich strategie się przenikają. Wobec tego medium traktuję dość szeroko, unikając tym samym sporów o samo znaczenie tego terminu. Interesuje mnie znacznie bardziej to, w jaki sposób poszczególne media się defragmentują lub łączą, jak współoddziaływują, w jaki sposób kodowana jest i dryfuje pomiędzy nimi informacja.

[2] Autorem terminu „transmedia” jest Henry Jenkins, obecnie jeden z najważniejszych teoretyków współczesnych mediów w Stanach Zjednoczonych, profesor w katedrze Komunikacji Dziennikarstwa i Sztuk Filmowych na Uniwersytecie Południowej Kalifornii, twórca i wieloletni kierownik programu Comparative Media Studies w Massachusetts Institute of Technology. W swojej wydanej w 2006 roku książce Convergence Culture szeroko dyskutuje znaczenie tego terminu, wskazując na różne aspekty współczesnego paradygmatu kultury opierającego się głównie na kategoriach „trans“ (geniczności, medialności, kulturowości, polityczności i strategii uczestnictwa).

Książka została przetłumaczona na język polski i wydana w 2008 roku. Zob. H. Jenkins, Kultura konwergencji. Zderzenie starych i nowych mediów, Warszawa 2008.

[3] Przez pojęcie „dane” rozumiem tu zarówno tradycyjnie pojmowane „informacje”, jak i elementy specyficzne i typowe dla poszczególnych mediów audiowizualnych. 
massmedia, a także sztuka) [4]. Dominującą cechą współczesnej komunikacji jest wobec tego przenoszenie niepowtarzalnych cech danego medium bądź określonej jego specyfiki lub strategii, w obszar innego medium. Proces ten nie dotyczy samych strategii komunikacyjnych i samych mediów. Transmedialność obserwujemy również na poziomie dyscyplin (na przykład naukowych i artystycznych). Transferowi mogą podlegać nie tylko ogólne zasady strukturalne, wrażliwość i specyficzna perspektywa medium bądź dyscypliny, ale także wspomniane powyżej strategie komunikacyjne, na przykład konstrukcje prezentacyjne, charakterystyczne schematy wizualne. Transwizualność jest immanentnie sprzęgnięta $\mathrm{z}$ nowymi formami percepcji, a także modelami pracy kreatorów wielokodowego komunikatu. Według Henry’ego Jenkinsa cyfrowy świat, w którym zbiegają się technologie i kultury, podlega ciągłym przemianom, jego struktura jest dynamiczna i możliwa do uchwycenia jedynie za pomocą metafory nazywającej naszą rzeczywistość „krajobrazem nowych mediów”.

Wydaje się, że termin transmedia nie tylko przynależny jest humanistyce ostatniej dekady, ale jego zakres znaczeniowy wchodził w skład podobnych mu koncepcji i zjawisk już w pierwszej awangardzie; takich jak choćby kino absolutne, którego różne formy eksplorowane były przez konstruktywistów, dadaistów i surrealistów, oraz późniejszych jego form w drugiej awangardzie w Stanach Zjednoczonych znanych jako kino rozszerzone czy też kino transgresji. To właśnie sztuka XX wieku laboratoryjnie przebadała możliwości komunikacyjne i doprowadziła do powstania narracji transmedialnych. Tego typu poszukiwania związane są z kształtowaniem się nowej wrażliwości percepcyjnej, moderowanej w pętli feedbackowej między będącą w ciągłym rozwoju technologiczną rzeczywistością oraz odbiorcą. Podchodząc w ten sposób do zagadnienia przenikających się kompetencji naukowych, artystycznych, środków ekspresji i różnorodnych strategii, warto dokonać drobnej retrospekcji i wspomnieć wybrane zjawiska artystyczne w XX wieku ukazane na tle ówczesnego krajobrazu technologicznego, które jednocześnie wyznaczają horyzont sztuki Roberta Wilsona.

Zapośredniczona przez nowe technologie rzeczywistość implikuje nową wrażliwość odbiorczą, z kolei ta stymuluje rozwój kolejnych narzędzi. To zjawisko stało się jedną z przyczyn poszukiwania nowych form sztuki w pierwszej połowie XX wieku. Z perspektywy historycznej istotnymi wydają się być poszukiwania w przestrzeni iluzji filmu i fotografii: Man Raya i Marcela Duchampa - op art, malarstwa: między innymi kubistów, abstrakcjonistów i surrealistów[5], dźwię-

[4] Jenkins podaje przykład transmedialnego opowiadania, analizując zarówno sam film Matrix, jak i zjawisko jego ciągłej obecności w kulturze za sprawą szeroko dostępnych wizerunków (gry wideo, partale społecznościowe fanów, logotypy, grafika, ikony, zabawki, ubiory, dzwonki telefoniczne, reklamy oraz tematy i motywy obecne w różnych innych formach sztuk).

[5] Pierwsza awangarda pełna była tego typu formalnych eksperymentów, podaję tutaj tylko wybrane przykłady, które najściślej wiążą się ze sztuką Roberta Wilsona. Temat eksperymentów z percepcją w ra- 
ku: choćby eksperymenty z hałasem Luigiego Russolo, przestrzeni i rzeźby: Kurta Schwittersa, światła: Laszla Moholy-Nagy’a i Oskara Schlemmera w Bauhausie[ $\left.{ }^{6}\right]$. Eksperymenty pierwszej awangardy polegały w głównej mierze na rozłączaniu kodów medialnych w danej sztuce, eksplorowaniu ich jako pojedynczych tworzyw, jak również ich możliwości komunikacyjnych. Rozłączne traktowanie linii kodów medialnych w takich sztukach jak teatr czy film, które z natury są wielokodowe umożliwiło poszukiwanie nowych rodzajów narracji i budowanie dramaturgii z napięć kształtujących się pomiędzy tymi liniami. Proces ten poza teorią artystyczną ma swoje źródło w rozwoju technologii. Pierwsza połowa dwudziestego wieku pozbawiona jest urządzenia, które w sposób kompleksowy (kompaktowy) umożliwiałoby rejestrowanie rzeczywistości, osobne narzędzia były w stanie rejestrować i przekazywać dane odpowiadające za dekodowanie dźwięku, obrazu ruchomego i nieruchomego. Z tego choćby względu poszukiwania awangardzistów wydają się być jak najbardziej zrozumiałe i uzasadnione.

W drugiej połowie XX wieku obserwujemy kontynuację procesu separacji kodów, ale także ponowną ich integrację, tyle że już na nowych zasadach i w nowym modelu sztuki i świata. Praca laboratoryjna, badająca i rozwijająca możliwości poszczególnych kodów, otrzymuje świeże stymulanty w postaci nowo pojawiających się rozwiązań technologicznych. Obok już ukonstytuowanych kierunków rozwijają się nowe: wideo art, light art[7], bio art, electronic art, net art, itd. Druga awangarda zerwała z klasyczną hierarchią kodów medialnych [8], zestawiając je obok siebie i czyniąc równorzędnymi. Nastąpił proces poszerzania ukonstytuowanych gatunków sztuki. Przymiotnik expanded (ang. poszerzony) pojawił się równolegle z myślą o nienazwanej jeszcze transmedialności. Poszerzone zostają najróżniejsze sztuki - expanded cinema, którego jednym z głównych animatorów i teoretyków w Nowym Jorku jest Jonas Mekas[9] - propaguje

mach różnych sztuk w sposób wyczerpujący omawia Rosalind E. Krauss w The Optical Unconscious, Cambridge - Massachusetts 1994. Rosalinde Krauss opisuje podświadomość optyczną, która w bardzo mocny sposób wpłynęła na artystów działających w latach 1920-1950: od Maxa Ernsta powieści-kolaży i hipnotycznych rotoreliefów Marcela Duchampa do tworzonych techniką drippingu płócien Jacksona Pollocka i świetlnych rzeżb Evy Hesse.

[6] Spektakl światta/eksperymenty ze świattem $w$ różnych formach z 1929 roku.

[7] Rozwój technologii świetlnej wymusił nowe przemiany tej formy sztuki, która od paru lat jest już raczej nazywana LED art (ze względu na korzystanie $\mathrm{z}$ oświetlenia ledowego).

[8] Problem ten jest szczegółowo omówiony między innymi w eseju wizualnym Intermedia Dicka Higgin- sa, jak również w jego tekście teoretycznym o tym samym tytule. Zob. D. Higgins, Intermedia, w: Nowoczesność od czasu postmodernizmu, Gdańsk 2000, s. 115-135.

[9] Jonas Mekas współpracuje z wieloma twórcami sceny nowojorskiej, filmując najważniejsze wydarzenia. Staje się jednym z istotniejszych dokumentalistów przemian artystycznych w Nowym Jorku w latach 6o. i 7o. W 1964 roku rejestruje spektakl The Brig Living Theatre, nagrywa wywiady z Georgem Maciunasem, założycielem Fluxusu, które zostają złożone w całość i wydane jako film Zefiro torna w 1992 roku. W latach 70. zakłada Anthology Film Archives przy 425 Lafayette Street, było to miejsce spotkań twórców, wymiany myśli, muzeum filmu awangardowego i niezależnego, przestrzeń wielu projekcji oraz biblioteka. 
interakcje obrazu filmowego z elementami pozafilmowymi. Na zorganizowanym w 1965 roku przez Mekasa festiwalu kina rozszerzonego, Robert Whitman pokazuje performance Prune Flat, w czasie którego zatracona zostaje granica pomiędzy rzeczywistymi występującymi przed widzami tancerzami[10], a ich zarejestrowanymi na taśmie filmowej i wyświetlanymi w tle wizerunkami. Innymi uczestnikami festiwalu byli: Robert Rauschenberg, Claes Oldenburg, Nam June Paik, La Monte Young, Marian Zazeela i Andy Warhol. Za kilka lat w Nowym Jorku pojawi się kolejny projekt, poszerzający ontologię obrazu filmowego o życie w jego wymiarze codziennym. Kino transgresji zostanie zapamiętane głównie dzięki biografiom artystów, którzy swoje życie uczynili podstawowym materiałem sztuki filmowej[11]. Równolegle do kina poszerzano inne sztuki, Dick Higgins anegdotycznie opisuje proces pojawienia się happeningu w twórczości Allana Kaprowa jako efekt kolaży, które nie mieściły się na płótnach, przybrały formy przestrzenne, a do ich wnętrza Kaprow wpuścił widzów [12]. Obok pojawiającej się transmedialności w sztuce wyłoniła się także nowa metoda tworzenia - model zapoczątkowany przez Johna Cage, Merce'a Cunninghama i Roberta Rauschenberga w Untitled Event z 1952 roku[13], jeszcze przez tych samych artystów został poszerzony o kompleksową współpracę kompetencji; już nie tylko różnych dyscyplin artystycznych, ale i technologii. Wielomediowe kody rozepchały granice sztuki i uczyniły ją jedną z gałęzi inkorporowania nowych technologii, jak też obszarem stymulującym poszukiwanie kolejnych innowacji technologicznych.

Sztuka stała się również przestrzenią prymarnych poszukiwań rozwiązań technologicznych (a więc nieistniejących jeszcze w przemyśle). Proces poszerzania przestrzeni sztuk i kompetencji artystów najlepiej uwidacznia przykład współpracy inżynierów i artystów w projekcie 9 Evenings Billego Klüvera i wspominanych wyżej: Cage'a, Rauschenberga, Whitmana i Cunninghama z 1966 roku. W czasie dziewięciu wieczorów zaprezentowano wydarzenia artystyczne, które były wynikiem kooperacji artystów i kolegów Klüvera z Laboratoriów Bella. Efektem tego była symbioza sztuki i technologii, polegająca na

[10] Do współpracy przy projekcie Whitman zaprosił Lucindę Childs, Simone Forti oraz Mimi Stark. [11] Najważniejszym twórcą tego nurtu był David Wojnarowicz, zmarły na AIDS w 1992 roku. Kino transgresji było jednym z wyraźniejszych głosów w sztuce, które odwołały się do innego jeszcze rozumienia transmedialności, łącząc ją z tkanką życia i dramatami wynikającymi z transgenderowości, transseksualności, transkulturowości itd. W latach 80. motywy transtożsamościowe stały się podstawowym tematem sztuki w ogóle. Do najważniejszych zjawisk należy tu choćby zaliczyć twórczość choreografa Billego T. Jonesa.
[12] Zob. D. Higgins, Intermedia, s. 121-122.

[13] W czasie Untitled Event obserwujemy rodzaj pracy, który można rozumieć jako punkt graniczny pomiędzy pierwszą a drugą awangardą. Artyści w czasie wydarzenia w Black Mountain Collage działali osobno w tym samym czasie i w tej samej przestrzeni każdy z nich pozostawał w interakcji z resztą, jednak dodatkowo każdy z nich eksplorował możliwości własnego kodu artystycznego. Nie może być tu zatem jeszcze mowy o transkompetencjach twórców. Efekt całościowy był wynikiem interakcji kodów i ich zespolenia w trakcie, na bieżąco powstającego zdarzenia artystycznego. 
równorzędnym traktowaniu jednej i drugiej dyscypliny[14]. Tryb pracy, który stworzyli artyści, technicy i inżynierowie stał się zaczątkiem nowego rozumienia i współistnienia takich przestrzeni jak sztuka, humanistyka i szeroko pojęta technologia. Model ten stał się podstawą rozwoju programów badawczych na takich uczelniach jak MIT i do dziś jest jednym z najistotniejszych kierunków rozwojowych[15].

W większości wydarzenia, o których tu mowa, miały miejsce w latach 60. i wczesnych 70. w Nowym Jorku, jak pisze Sally Banes w swojej książce Greenwich Village: „tamtejsza sztuka miała uprzywilejowane miejsce w kształtowaniu ówczesnej świadomości”[16]. Rozpoczęty przez europejskich artystów z kręgu awangardy proces laboratoryjnej pracy nad rozszczepianiem kodów medialnych znalazł swoje zakończenie, a na pewno zmienił swój charakter, w sztuce przełomu lat 60. i 70. w Nowym Jorku. Większość wyników eksperymentatorskiej pracy została wchłonięta przez nowe formy sztuk wykonawczych, których granic na dobrą sprawę nie można dziś określić. Dzieje się tak ze względu na przyjęty w tych latach paradygmat sztuki jako modelu nieustannie poszerzającego, zmieniającego i redefiniującego własne środki ekspresji, media, metody artykulacji i strategie. Właśnie ta, poddająca się bezustannie ruchowi, zasada nie domaga się jasnych podziałów na poszczególne dyscypliny artystyczne, ich kompetencje i specyficzne środki wyrazu. To z kolei pozwala widzieć ją jako jedną z bezpośrednich źródeł dzisiejszej transmedialności.

W tym czasie - w drugiej połowie lat 6o. - przyjeżdża do Nowego Jorku Robert Wilson i zaczyna swoje poszukiwania artystyczne w przestrzeni właśnie transmedialności. Ten percepcyjno-kreacyjny model stanie się elementem ukrytym i immanentnym jego warsztatu technicznego, jego pracy jako zawodowego reżysera, projektanta, architekta, artysty wizualnego, a także, o czym nie można zapomnieć, terapeuty. Przez następne lata Wilson wspóluczestniczy bardzo intensywnie w artystycznym życiu miasta. Wychodząc od tańca postmodernistycznego, performance artu, projekcji filmowych i instalacji, zaczyna wykorzystywać narzędzia technologiczne do poszerzania sztuk wykonawczych i inicjuje proces transmediacji pomiędzy ich kompetencjami.

[14] Projekt 9 Evenings, jako jeden z pierwszych, opierał się na ścisłej współpracy artystyczno-inżynierskiej, po raz pierwszy w sztuce wykorzystano rozwiązania, które nie zostały jeszcze w pełni wprowadzone do przemysłu, takie jak fotokomórka i skonstruowane specjalnie na potrzeby projektu Rauschenberga Open Score mikroprzekaźniki radiowe. Innym ważnym faktem było wykorzystanie publicznej sieci telefonicznej do transmisji „danych” z przestrzeni miasta Nowy Jork, które później były na żywo przetwarzane w miejscu, gdzie odbywał się performance (Variations VII Johna Cage'a).
[15] Szczególnie żywy rozwój współpracy pomiędzy dyscyplinami sztuki, humanistyki i technologii przypada w MIT na lata 1966-1980, kiedy to wprowadzono na uczelnię nowe kierunki artystyczne, humanistyczne i społeczne. Takie badanie, jakie prowadził na MIT Henry Jenkins, nie byłyby możliwe bez zmiany paradygmatu uczelni w latach 60.

[16] S. Banes, Greenwich Village 1963: Avant-Garde Performance and the Effervescent Body, New York 1993, s. 3. 
PRZESTRZEŃ

POSZERZONA

Jest rok 1965. Robert Wilson, który przyjechał z Waco w Teksasie do Nowego Jorku, jest studentem architektury w Pratt Institute na Brooklynie (Nowy Jork) i uczestniczy w zajęciach fakultatywnych, prowadzonych wówczas w ramach tzw. programu tanecznego. Wynajmuje Peerless Movie House i realizuje swój pierwszy solo projekt sceniczny zatułowany Dance Pieces (Fragmenty taneczne). Nagrania $\mathrm{z}$ tego przedsięwzięcia pokazują przyszłego reżysera teatralnego w sytuacji improwizacji taneczno-ruchowej: Wilson chodzi, biega, skacze, wymachuje rękoma, obraca się, wykonuje rozmaite codzienne czynności, które - powtarzane w określonym rytmie i wyznaczonej precyzyjnie przestrzeni - nabierają cech abstrakcyjnych, używa także projekcji filmowych i niezależnej od ruchu warstwy dźwiękowo-rytmicznej. George Klauberg, jego ówczesny mentor w Pratt, wspomina, że zdarzenia, performance, etiudy, nad którymi pracował wówczas Wilson, były niczym wizualne tableaux, pozbawione słów projekcje, jedynie $\mathrm{z}$ fragmentami muzycznymi.

Nie były właściwie tańcem - mówi Klauberg - to był rodzaj niemal spastycznych ruchów, oczywiście wykonywanych w sposób zamierzony. Uczestnicy programu tanecznego nie przepadali za sposobem wyrazu używanym przez Wilsona (ponieważ nie miało to nic wspólnego z baletem), ale dla widza to było niezapomniane doświadczenie [ $\left.{ }^{\mathbf{1 7}}\right]$.

Kiedy Wilson studiował w Pratt był też uczniem George’a McNeila[ $\left.{ }^{18}\right]$, który pokazywał mu, jak łączyć techniki różnych sztuk: muzyki (był pod silnym wpływem Igora Strawińskiego), tańca (znał choreografie Marthy Graham czy George'a Balanchina[19]) w ramach malarstwa. McNeil był jednocześnie pod dużym wpływem twórczości Hansa Hoffmana, należącego do pierwszej generacji malarzy spod znaku abstrakcji ekspresjonistycznej. Największe jednak emocje wzbudzały zajęcia Sybil Moholy-Nagy (wdowy po László Moholy-Nagy)[20]. W projekcie grupy Bauhaus, który omawiała artystka, zapewne zainteresowało Wilsona: położenie nacisku na relację człowieka-tancerza (jak go nazywał niegdyś Oskar Schlemmer) do jakości przestrzennych; do geometrycznego, abstrakcyjnego, determinującego ruch wykonawców kostiumu; do ustrukturowanej (niemalże według zasad matematycznych, inżynierskich)[21] całości przedstawienia. Równie ważna była możliwość osobnego traktowania kodów medialnych, wykorzystywania rozmaitych narzędzi (między innymi różnego typu projekcji, jakie były wówczas możliwe) czy tworzenia architektoniki spektaklu wyłącznie ze światła i ruchu aktora. Eksperymenty twórców Bauhausu zainspirowały Wilsona do

[17] Ibidem, s. 43-44.

[18] Spotykał się z nim w Paryżu.

[19] Twórczość obu tych artystów ceni Wilson, warto zaznaczyć, że brał lekcje u Marthy Graham.

[20] S. Brecht, Robert Wilson. The Theatre of Visions, London 1994, s. 16-17.
[21] Twórcy Bauhausu w Niemczech w latach 20. i 30. prowadzili szeroką współpracę z wieloma gałęziami przemysłu. Ich eksperymenty w większości byłyby niemożliwe gdyby nie zaangażowanie inżynierów. 
rozwijania koncepcji wielomedialności w sztukach wykonawczych. Przy czym polimedialność nie oznaczała tutaj kontaminowania kodów, a raczej poszukiwanie transrelacji pomiędzy kodami medialnymi różnych sztuk a ich indywidualnymi narracjami. $Z$ tego też powodu eksperymenty Wilsona nie ograniczyły się do teatru. Twórca w pracy eksperymentalnej sięgnął po różne narzędzia $\mathrm{z}$ wielu nurtów w sztuce współczesnej, między innymi: taniec postmodernistyczny, performance art, instalację, wideo art, audio art, light art, land art; a potem także po nową technologię, choćby spod znaku motion capture.

Już na początku swojej drogi artystycznej Wilson podjął próbę zmierzenia się - jako wykonawca - z przestrzenią i czasem, którym operuje sztuka oparta na ruchu ciała. Co ciekawe, jest to przecież podstawowy problem projektantów urządzeń rejestrujących warstwy rzeczywistości. Wilson ma świadomość tego, że doskonałe odwzorowanie jest niemożliwe, błędy technologiczne zawsze się pojawiają. I właśnie to staje się dla niego inspiracją. Rzeczywistość sztuki Wilsona skupia się na obrazie „zdeformowanym”, z zafałszowaniem czasu i przestrzeni, poddaje go obróbce i manipulacji, w ten sposób otrzymuje inny obraz. Jest on z jednej strony zakłamanym odwzorowaniem rzeczywistości w sensie technologicznym (kamera), z drugiej zaś - optyczną podświadomością naszej percepcji (ludzkie oko), pełnej defektów, często niespójnej i obciążonej błędami, niekoherentnej w swoich warstwach dźwiękowych, optycznych i sensorycznych. Ludzki mózg stara się sobie radzić z tym marginesem błędu, spychając go najczęściej w nieświadomość. Skoro ludzkie oko i ucho podatne są na niego, to właśnie ten margines deformacji, według Wilsona, należy eksplorować w sensie artystycznym. RoseLee Goldberg opisuje ten wspólny dla wielu ówczesnych artystów, w tym także Roberta Wilsona, proces:

Przestrzeń była eksplorowana jako ruch i wizualna płaszczyzna, słowo mówione jako dźwięk raczej niż narracja; muzyka jako notacja i architektonika raczej niż rytm, melodia czy harmonia; ciało jako łącznik wszystkich tych elementów. Żaden z tych elementów nie wynikał bezpośrednio $\mathrm{z}$ tradycji teatru. [...] Żaden z tych artystów nie był zainteresowany skomplikowaną i psychologiczną grą aktorską [...] ani burzeniem czwartej ściany, by agitować publiczność i wzbudzać w niej empatię. Artyści ci byli performerami, reżyserami, scenarzystami, architektami, choreografami w jednej osobie, scena była dla nich laboratorium eksperymentów wizualnych i percepcyjnych. Wykonawca był fizycznym narzędziem wyznaczającym przestrzeń i tekst, tak jak muzyka była narzędziem tworzącym obrazy wizualne [...], mogły być one powoli i niezauważalnie rozpuszczane w sobie nawzajem, tworząc pozbawiony wewnętrznych relacji trójwymiarowy obraz. Reakcja odbiorców miała mieć raczej charakter reakcji bezwarunkowej (instynktownej). Dopiero później widzowie mogli znaleźć słowa, aby opisać relacje pomiędzy uczuciami a ideami, których doświadczali wizualnie $\left[{ }^{\mathbf{2 2}}\right]$.

[22] R. Goldberg, Performance. Live Art Since the 60s, New York 2004, s. 21-22. 
Ten rodzaj technologiczno-organoleptycznego doświadczenia, a także transgenicznego traktowania sztuk, splótł się w pracy zawodowej Wilsona z jego wieloletnią praktyką terapeuty.

Poszukiwanie nowych relacji między elementami w dziele ma według Wilsona konstruować świat artystyczny tak, by poruszył, ale i zaburzył zmysły odbiorcy. Wiele pytań, które artysta stawiał swojej sztuce, wynika niemal bezpośrednio z jego doświadczeń kontaktu z ludźmi niepełnosprawnymi. Wilson przez wiele lat pracował z pacjentami szpitali psychiatrycznych i ośrodków terapeutycznych; próbował leczyć ich poprzez ruch, działania, odkrywając między nimi pozawerbalną nić komunikacji. Afabularność, nielinearność, specyficzna wizualność w sztuce Wilsona mocno zakorzeniona jest w jego działalności pozaartystycznej, nie rozdzielał on bowiem nigdy tych dwóch sfer. Poprzez sztukę ruchu leczył, od tych których leczył, uczył się innego sposobu widzenia zjawisk w rzeczywistości i pozawerbalnej komunikacji. „Zajmowałem się ludźmi z uszkodzeniem mózgu - wspomina niejednokrotnie Wilson - z ADHD, katatonikami. Moim zadaniem było sprawienie, by zaczęli mówić[23]".

W 1971 roku Wilson pokazuje w Paryżu spektakl, który porusza francuskie (i nie tylko) kręgi artystyczne, jednocześnie ze względu na tematykę i sposób jej ujęcia dzieli odbiorców. Zachwycony jest miedzy innymi Luis Aragon - po premierze pisze, że to „prawdziwy cud, który uzdrowi naszą umierającą sztukę. Krytykuje bowiem wszystko do czego przywykliśmy" [24]. Przedstawienie, o którym mowa, nosiło tytuł Deafman Glance, główną rolę grał w nim głuchoniemy afroamerykański chłopiec - Raymond Andrews. Wilson niegdyś poznał go w New Jersey, zaadoptował i zaczął z nim pracować. Jak sam często wspomina, zrozumiał, że musi nauczyć się języka Raymonda, czyli poznać świat jego wyobraźni, jego strukturę i zawarte w niej emocje, a także formy ich komunikacji. To wszystko odzwierciedlały szkice, obrazy chłopca, które stały się kanwą formalną dla całego spektaklu, stanowiły jego warstwę tekstualną. Odrzucone obrazy, margines optycznego i audialnego ludzkiego błędu, zepchnięty przez mózg w podświadomość, stał się tutaj kodem prymarnym. Jednocześnie Wilson zwrócił uwagę na to, że ludzka percepcja nie operuje pojęciem normy. W związku z tym jej wyznaczanie jest arbitralnym wykluczaniem części naszej rzeczywistości, która z przymusu zostaje zepchnięta w głębokie struktury mózgu. W pracy tej Wilson nie użył żadnego dźwięku, była to jedna z cyklu tzw. niemych oper. Brak klasycznej fabuły i perypetii zmuszał widza do poszukiwania innego sposobu czytania tekstu teatralnego, właśnie poprzez obrazy, rytm, ruch, barwy, co jednak istotne - zmierzenia się równocześnie z ciszą trwającą podczas czterogodzinnego niemal spektaklu. Już w tym przedsięwzięciu widać

[23] Cyt. za: A. Holmberg, The Theatre of Robert Wilson. Directors in Perspective, Cambridge 1996, s. 3 .
[24] L. Aragon, Lettre ouverte a André Breton, „Les Lettres Franćaises" 1971 (June 2-8). Cyt. za: A. Holmberg, op. cit., s. 5-6. 
charakterystyczny dla tego reżysera sposób uruchamiania wykonawców. Wówczas pracował jeszcze z amatorami, których skupił wokół siebie w szkole Byrd Hoffman, ćwiczył z nimi w swoim lofcie na Manhattanie. W ramach warsztatów uczyli się oni sposobów chodzenia, siadania, interakcji między nimi samymi a przedmiotami, jak też wykonywania tych czynności w różnym tempie. $\mathrm{Z}$ improwizowanych działań powstały partytury, które weszły w skład spektaklu. W 1981 roku Wilson stworzył wersję wideo Deafman Glance, w ten sposób wyraźnie dał do zrozumienia, że nie chodzi wyłącznie o teatr, ale o efekt, który można osiągnąć za pomocą różnych sztuk i mediów, wielu kodów. Chodzi o czystą wizualność, nie obciążoną zewnętrznymi kategoriami rzeczywistości, jak normy poprawności i świadomości. Wizualność rozszerzoną.

Wilson pracuje osobno z ruchem aktorów i obiektów, tekstem; rozdzielnie tworzy reżyserię światła i architektonikę dźwięku, projekcje. Od wielu lat współpracuje z takimi kompozytorami, jak Philip Glass, Tom Waits, Peter Kuhn, Lou Reed, autorami tekstów: Williamem S. Burroughsem, Heinerem Müllerem, Susan Sontag, specjalistami od nowych mediów, choreografami. Jego praca w każdym z tych kodów buduje osobne linie dramaturgiczne i wynika z konglomeratu jego własnych doświadczeń jako: architekta, performera, artysty wizualnego i terapeuty. Transmedialność sztuki Wilsona kształtuje się nie tylko na poziomie efektu artystycznego, ale jest także immanentną częścią procesu twórczego. Wilson to reżyser-projektant-inżynier. Jego podejście do pracy z materią teatralną bliższe jest kompetencjom współczesnego artysty wizualnego posługującego się nowoczesnymi narzędziami technologicznymi. Transmedialność ma przynajmniej dwa wymiary w pracy Wilsona. Po pierwsze, jest związana z polimedialnym tworzywem spektaklu, po drugie, z samym procesem pracy z poszczególnymi pojedynczymi kodami, w których wykorzystuje różne narzędzia. Programując światło sceniczne, Wilson łączy kompetencje fotografa, operatora kamery, artysty instalacji, a co ciekawsze, kompozytora, który traktuje fotony jak struktury muzyczne. Całość transmedialnego komunikatu podlega rygorystycznej formie i wytycznym Wilsona-projektanta, który dba o to, by wszystkie poszczególne układy były kompatybilne. Proces rozwijania dramaturgii jednego kodu medialnego najlepiej prześledzić na przykładzie pracy $\mathrm{z}$ aktorem.

W jego spektaklach struktura działań aktorskich jest tak konstruowana, by nie ilustrowała tekstu, ale by była w opozycji do semantyki słowa, przekraczała codzienność i potoczność ruchu, stanowiła ściśle opracowaną formę. Działania fizyczne są więc dla niego osobną linią dramaturgiczną i semantyczną, jednocześnie oparte są na pewnych zasadach, tworzących spójny kod. Jego stosunek do słowa (które jest drugorzędne i często celowo pozbawione prymarnych kulturowych czy tradycyjnych kontekstów semantycznych) nie wyklucza tego, 
że właściwie werbalizuje on działania aktorskie na scenie. Z nich właśnie buduje język, ustalając partyturę ruchową - myśli gramatyką języka. Aktor uprzestrzenniony staje się aktorem tekstualnym - hieroglifem, tworzy pismo ze znaków niewerbalnych. Zarówno gestyka, jak i inne działania fizyczne komponowane są z jednostek podstawowych, które Wilson wypracowuje i zafiksowuje jako swoisty rodzaj elementów aktorskiej choreografii. Opiera się ona na kilku zasadach: oszczędności działań, ich rytmiczności i powtarzalności, geometryzowaniu emocji i korespondencji z innymi kodami dzieła. Oczywistym staje się fakt, jak wiele wniosków wyciągnął Wilson z doświadczeń tańca współczesnego.

Każde działanie aktorskie, nawet najprostsze, jak chodzenie, siadanie, wskazywanie, bieganie jest komponowane poprzez różne soczewki medialne. Jest to proces obróbki estetycznej, która polega na wydobyciu z nich ich formy i skonfrontowaniu jej bądź nawet oderwaniu od znaczenia czy funkcji, jakie są jej zwyczajowo przypisane. Artysta najczęściej opiera swój kod aktorski na kilku podstawowych ruchach, z których najbardziej charakterystyczne są: chodzenie i wskazywanie (esencja ruchu i gestyki). Na bazie tych dwóch podstawowych działań buduje on partyturę dla spektaklu. Tworzy inwariantną technikę aktorską, która podlega modyfikacjom w ramach konkretnego przedstawienia. Do tego dołącza rozbudowaną gestykę, z której każdy element, szczegół ma swoje miejsce i znaczenie. Ale znaczenie to, po pierwsze, nie zawsze ma proste przełożenie na kategorie życiowe, po drugie - jest niedookreślone. Jeśli bowiem aktor wykonuje dany gest to jego semantyka jest dookreślana przez światło, konstrukcje przestrzenne, także barwy, dźwięki czy wypowiadane słowo, a zatem inne kody. Dlatego poszczególne elementy partytury działań fizycznych mogą nabierać różnych znaczeń w zależności od sytuacji kontekstowej, co pomimo rygorystycznego kodu daje artyście duże możliwości operacyjne.

We wstępie do filmowej dokumentacji spektaklu Madama Butterfly z 2003 roku artysta mówi wyraźnie:

Najpierw ułożyłem sobie całą sztukę w ciszy, bez muzyki. Ruch musi być osobny. Nie zaczynam od muzyki. Zawsze rozpoczynam od ruchu. Niektórzy antropologowie wierzą, że człowiek najpierw się poruszał, zanim mówił. I to z ruchu narodził się dźwięk. [...] Na początku sam zagrałem Madama Butterfly (nie tylko bohaterkę, również pozostałe postaci) i nagrałem to. Potem mogli się z tego uczyć inni. Następnie przeglądałem kasetę i notowałem ruch - przypisując poszczególnym fragmentom kolejne liczby. Wówczas dopiero słuchałem muzyki i umiejscawiałem ruch. [...] Jest to muzyczna partytura ruchu i światła[ $\left.{ }^{25}\right]$.

Cytat ten uwypukla system pracy Wilsona, który korzysta z technik różnych sztuk, pracując w teatrze.

[25] Pełna wersja wypowiedzi zob. Wprowadzenie do filmu dokumentującego spektakl Madama Butter-

fly, Opus Arte (2005). 
Najbardziej charakterystycznym chwytem, który stosuje Wilson, by proste czynności odrealnić i uczynić immanentnymi częściami formy dzieła, jest poddanie ich różnym strukturom rytmicznym stąd na przykład z jednej strony słynne już slow motion, a z drugiej zaś bardzo szybkie powtarzanie pojedynczych gestów. Użycie tego typu chwytów ma w sposób oczywisty zaktywizować widza. Najpierw wybić go z potocznego i zwyczajowego odbioru ruchu i elementów przestrzeni, jak też barw (kostiumy i tło, na którym poruszają się aktorzy). Widz niekoniecznie ma stosować zasady analizy psychologicznej, ale raczej zdać się na to, co dzieje się z nim, gdy ogląda samą kompozycję dynamicznej formy.

Trajektoria ruchu postaci, precyzyjnie wyznaczona gestyka, rozpatrywane są zawsze odniesieniu do kategorii przestrzennych. Aktorzy przemieszczają się w przestrzeni, wyznaczając jej głębię, długość, szerokość. Wykreślają geometrię i czas przestrzeni. Większość postaci, które się pojawiają, wchodzi na tle horyzontu; ponieważ są oświetlone od tyłu i zaciemnione z przodu wyglądają jak płaskie figury - reliefy; przemierzają w różnym tempie linię horyzontu, by nagle wkroczyć w przestrzeń kubiczną i nabrać trójwymiarowego kształtu, po czym znów obrócić się o 90 stopni i utrzymując formę profilu, opuścić scenę. W tym przypadku Wilson zachowuje się równocześnie jak fotograf w studiu, portretujący nieruchomego modela oraz operator kamery na planie filmowym, chcący zwaloryzować przestrzeń światłem.

Znamiona przestrzenne posiada również wypowiadany przez postaci tekst. Zgłoski, sylaby przeciągane są niczym dźwięki, fragmenty zdań są multiplikowane, urywane w połowie czy zawieszane. Rytmizacja tekstu zawsze podlega dynamice czasoprzestrzeni, nigdy zaś semantyce. Tutaj Wilson pracuje jak realizator dźwięku w studiu nagraniowym lub eksperymentujący z wielościeżkowymi nagraniami artysta audio artu, zapętlając, powielając, deformując, opóźniając i przyspieszając względem siebie materiał dźwiękowy.

W każdym tekście (czy będzie to dramat Georga Büchnera, Williama Szekspira, Heinera Müllera) Wilson odczytuje indywidualną architektonikę zgłosek, wyrazów i zdań. Interpretując tekst, myśli najpierw o odległościach między zdaniami, słowami, o ich kształtach i kolorach, dopiero później o ich semantyce. Używając metafory technologicznej - cały materiał zgromadzony w spektaklu jest poddawany procesowi postprodukcji, w czasie którego wszystkie składowe elementy podlegają ponownemu montażowi i ewentualnym poprawkom, tworząc nową jakość.

Bycie aktorem w teatrze Wilsona znaczy bycie funkcją przestrzeni, ale też tworzenie tej przestrzeni. Posługując się formułą Władimira Toporowa, który pisał o rozmaitych związkach między przestrzenią i rzeczami, miejscami oraz ludźmi, można by wręcz powiedzieć, że przestrzeń jest w takiej relacji do aktorów, iż jest ni- 
czym więcej jak tylko ich rozprzestrzenieniem.[26] Nie ma więc przestrzeni teatru Wilsona bez aktorów, to oni ją wykreślają, wykreślając dzieło.

Również afekty, emocje, odczucia przedstawiane są za pomocą linii, form i barw. Widz odczytuje je z kompozycji całości, nie zaś jedynie $\mathrm{z}$ emocji przekazywanych przez samych aktorów. „Prywatne” emocje aktorów są istotne, ale ulegają przetopieniu, wnikają w siatkę przestrzenną, w której istnieje aktor. I czasem najwięcej o emocjach postaci mówi linia, po której porusza się aktor, sposób, w jaki to wykonuje, barwa tła czy jego oświetlenie. Aktor swoimi emocjami wypełnia partyturę działań. Dopiero wówczas nabiera ona pełnego wyrazu, nabiera wyrazu artystycznego, nie pozostaje jedynie wirtuozerskim wykonaniem formy. Dlatego wbrew potocznym opiniom aktorstwo $\mathrm{w}$ teatrze Wilsona jest aktem kreacji, który uwzględnia prymarne istnienie pewnego uniwersalnego kodu aktorskiego[27].

W sztuce Wilsona poprzez owy kod działań człowiek przeistacza się na scenie w symbol. Twarz jego staje się maską albo portretem, projekcją, wycinkiem całości, ciało - zarysem, poza - rysunkiem, ruch - rytualną plastycznością albo tańcem, głos - muzyką. Wykonawca staje się nośnikiem polimedialnego kodu. Bardzo ważną funkcję w teatrze amerykańskiego reżysera odgrywa również sama twarz wykonawcy. Jest ona niczym maska, wyklucza przypadkowe emocje. Funkcja twarzy-maski (jako układu mięśni mimicznych, które aktor stara się „trzymać”, podkreślona makijażem) i działań aktorskich związana jest też z deformacją ich rzeczywistych odpowiedników, ich groteskową wersją. Wilson doskonale operuje kategorią postekspresjonistycznej groteski. Zdarza się to między innymi wtedy, gdy kod, który stosują aktorzy w czasie spektaklu, jest jednocześnie poddawany na scenie dekonstrukcji. Dokonuje się to poprzez bardzo proste zabiegi: na przykład hieratyczny ruch aktora po diagonalu wprowadza widza w określony stan emocjonalny, po czym następuje nagły zwrot twarzą do widowni i wykrzywienie tej twarzy w przerysowanym grymasie oraz użycie światła punktowego.

Wilson często powtarza, że ustalony język z widownią trzeba burzyć, niszczyć i na bazie zdekonstruowanych elementów na oczach widza budować nowy. I często podaje przykład Marleny Dietrich, która potrafiła trzy razy obracać głowę w tył w prawo i w sposób niesamowity, używając jedynie ruchu oczu łamać ten kod - za czwartym razem, poruszając delikatnie oczami w lewo. Precyzja, wystudiowana technika i dystans czyniły ją fascynującym obiektem.

Groteska buduje się też w ramach zestawiania różnych linii dramaturgicznych, co daje możliwości pokazywania wielu wymiarów natury zjawisk i postaci. W prowadza też humor, grę, żart do precyzyjnej,

[26] W.N. Toporow, Przestrzeń i rzecz, przeł. B. Żyłko, Kraków 2003, s. 29.
[27] Podobne myślenie o aktorstwie zresztą jest zapisane w wielowiekowej tradycji teatru, szczególnie teatru Wschodu. 
trwałej estetycznej konstrukcji. Tekst teatralny Wilsona zbudowany jest z molekuł, które układają się w sposób indywidualny i jednorazowy w zderzeniu z widzem, choć są elementami ściśle opracowanej struktury. Reżyser zapewne chciałby, by kod aktorski, który wypracował stał się ponadkulturowym, uniwersalnym sposobem komunikowania sztuki i odbiorcy. Językiem pozawerbalnym, opartym na tym, co widzimy i słyszymy, niekoniecznie jednocześnie. Po prostu kodem transmedialnym. Analizując sztukę Wilsona, nie jesteśmy w stanie definiować i wskazywać granic poszczególnych mediów (na przykład aktora, światła, dźwięku) jako osobnych, skończonych i stałych elementów szerokiej struktury komunikacji. Kompetencje aktora przenosić się mogą na światło, przestrzeń lub dźwięk, jak i odwrotnie[28].

W związku z wyczerpaniem intermedialnego modelu sztuk, mediów i ich narzędzi stoimy dziś wobec zarysowującego się już bardzo wyraźnie problemu transmedialności, a wraz z nim z zagadnieniami transgeniczności, transnarzędziowości, transpercepcji, a może nawet transkompetencji sztuki. W XX wieku rozwijająca się technologia, pojawiające się nowe i redefiniujące swoje możliwości stare kody medialne zmieniły myślenie nie tylko o teatrze, ale także o każdej dyscyplinie sztuki, w której naturze leży wielotworzywowość. Każde nowopowstałe medium i jego narzędzia, takie jak choćby rejestratory dźwięku i obrazu, posiadają swoje specyficzne i przynależne tylko im samym narracje. Są one częścią ontologii tych narzędzi i mediów. W ten sposób tworzony jest dzisiejszy „krajobraz medialny”. Współcześni twórcy myślą transmediami. Tacy reżyserzy jak Robert Wilson myślą sztukami audowizualnymi i filmem w teatrze. Nie oznacza to wprowadzania tych mediów do wnętrza spektaklu, tylko używania ich narzędzi, wykorzystywania ich specyficznych i niepowtarzalnych narracji. Paradoksalnie Robert Wilson, rozpoczynając swoją drogę artystyczną od inspiracji landscape play Gertrude Stein[29], dziś funkcjonuje w obrębie landscape media. Potwierdzają to jego fenomenalne projekty takie jak Voom Portraits, będące grą pomiędzy grafiką, wideo artem, audio artem, instalacją a klasycznym malarstwem portretowym. Tworząc Voom Portraits w 2004 roku, Robert Wilson po raz kolejny przedefiniował formy współczesnej sztuki. Zawieszone w popkulturze portrety rozpoznawalnych aktorów i artystów[30], zderzone są z historią malarstwa i wizualną wrażliwością wideo w wysokiej rozdzielczości oraz szczegółowo dopracowywaną ścieżką dźwiękową.

[28] Por. przypis 1.

[29] Teksty Gertrude Stein dopiero dzięki Wilsonowi znalazły kongenialną wręcz realizację sceniczną. (Wilson twierdził, że to właśnie lektura tekstów Stein przekonała go, że jest w stanie robić teatr). H.-T. Lehmann, Teatr postdramatyczny, przeł. D. Sajewska i M. Sugiera, Kraków 2004, s. 65.
TRANSKOMPETENCJE SZTUKI
[30] W formie zapętlonych filmów wideo sportretowani zostali między innymi Brad Pitt, Juliette Binoche, Steve Buscemi, Isabelle Huppert, Marianne Faithfull, Willem Defoe, Lucinda Childs. 
Każdy portret-projekcja wydaje się być niezależny i funkcjonować osobno, jednak w rzeczywistości całość komponowana jest w rodzaj instalacji, której elementy mają charakter konstelacyjny. Wilson nie zatrzymuje się w swoich poszukiwaniach, strategie transmedialne przestają wystarczać, nowe projekty takie jak Voom Portraits zaczynają penetrować przestrzenie transpercepcji związanej z kategoriami synestezyjności sztuk audio, wideo i instalacji, zachowującymi w dalszym ciągu swój potencjał ukrytych w nich sztuk wykonawczych. W ten sposób, na nowej zasadzie, nawiązuje do pierwszej awangardy, ponownie podejmując laboratoryjną pracę z możliwościami percepcyjnymi różnych kodów. 